\title{
GROWTH, NODULATION AND NITROGEN FIXATION OF COWPEA IN SOILS AMENDED WITH COMPOSTED TANNERY SLUDGE ${ }^{(1)}$
}

\author{
Joseany Andrade Santos ${ }^{(2)}$, Luís Alfredo Pinheiro Leal \\ Nunes $^{(3)}$, Wanderley José de Melo ${ }^{(4)}$, Marcia Barreto do Vale \\ Figueiredo $^{(5)}$, Rajeev Pratap Singh ${ }^{(6)}$, Antônio Aécio Carvalho \\ Bezerra $^{(3)}$ \& Ademir Sérgio Ferreira de Araújo ${ }^{(3)}$
}

\begin{abstract}
SUMMARY
Tannery wastes generation is increasing every year and a suitable method for tannery sludge management is necessary in order to decrease this environmental problem. The composting is recognized as a suitable method for sludge recycling.. The effect of tannery sludge compost (TSC) rates on growth, nodulation and $\mathrm{N}$ fixation of cowpea was investigated. Sandy and clayey soils were amended with TSC at rates of $0,7.5,15,30$, and $60 \mathrm{t} \mathrm{ha}^{-1}$. The shoot dry weight of cowpea plants 45 days after emergence (DAE) was greater in the TSC-amended than in the unamended soil. In the sandy soil, nodule dry weight increased with TSC application 45 DAE. In the clayey soil, 45 DAE, nodule dry weight decreased with TSC amendment levels greater than $7.5 \mathrm{t} \mathrm{ha}^{-1}$ compared to the unamended control. The application of TSC increased $\mathrm{N}$ accumulation in the cowpea plants. The results suggest that cowpea responds differently to TSC depending on the amendment rate and initial soil type.
\end{abstract}

Index terms: waste, soil texture, composting, heavy metal.

\footnotetext{
(1) Part of Dissertation of Master degree from first author presented for Post-Graduation Program of Agronomy (PPGA), Agricultural Science Center (CCA), Federal University of Piauí (UFPI). Received for publication in November 28, 2010 and approved September 15, 2011.

${ }^{(2)}$ Master Student from PPGA, Federal University of Piauí, Campus Minister Petrônio Portela, s/n, Ininga Town, 64049-550 Teresina (PI), Brazil. E-mail: joseanyandrade@gmail.com

(3) Professor, Faculty of Agronomy, CCA, UFPI, Teresina (PI), Brazil. Fellow from CNPq. E-mails: asfaruaj@yahoo.com.br; lalnunes@yahoo.com.br; aecio@ufpi.edu.br

(4) Professor, São Paulo State University, UNESP, Faculty of Animal and Agricultural Science, FCAV, Jaboticabal (SP), Brazil. Fellow from CNPq. E-mail: wjmelo@fcav.unesp.br

${ }^{(5)}$ Researcher, Agronomic Institute of Pernambuco, IPA, Recife (PE), Brazil. Fellow from CNPq. E-mail: marcia.figueiredo@pq.cnpq.br

(6) Professor, Institute of Environment and Sustainable Development, Banaras Hindu University, Varanasi, India-221005. Email: rajeevpratap@yahoo.com
} 


\title{
RESUMO: CRESCIMENTO, NODULAÇÃO E FIXAÇÃO DE NITROGÊENIO PELO FEIJÃO-CAUPI EM SOLO COM COMPOSTODE LODO DE CURTUME
}

\begin{abstract}
A geração de resíduos de curtume está aumentando a cada ano e um método adequado para o manejo do resíduo de curtume é necessário para diminuir o problema ambiental. A compostagem é reconhecido como um método adequado para a reciclagem do lodo. O objetivo do trabalho foi investigar o efeito da aplicação de composto de lodo de curtume (CLC) sobre o crescimento, nodulação e acumulação de nitrogênio do feijão-caupi. Solos arenoso e argiloso

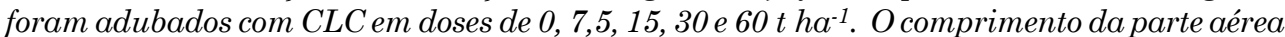
do feijão-caupi foi maior, aos 45 dias após a emergência das plantas (DAE), no solo com aplicação de CLC do que no solo sem aplicação. No solo arenoso, a massa dos nódulos, aos $45 \mathrm{DAE}$, aumentou com a aplicação do CLC. No solo argiloso, aos $45 \mathrm{DAE}$, em doses superiores a 7,5 tha-1, houve um decréscimo na massa nodular quando comparado ao solo sem aplicação. A aplicação do CLC aumentou a acumulação de $N$ nas plantas de feijão-caupi. Os resultados sugerem que o feijão-caupi responde diferentemente ao CLC sendo dependente da dose de aplicação e do tipo de solo.
\end{abstract}

Palavras-chave: resíduo; textura do solo, compostagem, metal pesado.

\section{INTRODUCTION}

The leather tanning industry plays an important role in the Brazilian economy, with assets of about 21 billion dollars. However, this industry is also responsible for the release of more than $1,000,000$ tons of tannery sludge each year (Pacheco, 2009), of which $3 \%$ are solid residues (Silveira et al., 2002). The high annual production of tannery sludge has created a series of economic, social and environmental problems. In Brazil, there is currently no appropriate disposal method for tannery sludge, so most often the residue is simply sent to a landfill. Tannery sludge usually contains high levels of organic matter, chemical nutrients and heavy metals, mainly $\mathrm{Cr}^{3+}$ (Castilhos et al., 2002). The occurrence of metals in complex form, especially $\mathrm{Cr}, \mathrm{Fe}, \mathrm{Mn}, \mathrm{Zn}, \mathrm{Cu}, \mathrm{Pb}, \mathrm{Ni}$, and $\mathrm{Cd}$ in tannery sludge is a cause of serious concern because of the risks they pose to human health, particularly the danger of food chain contamination (Gupta \& Sinha, 2007).

Landfilling and land application of the sludge are commonly the most recommended disposal techniques (Singh \& Agrawal, 2008, 2009). However, landfills are often not a suitable disposal option in view of the large volume of soil required to cover the waste to prevent leaching of potentially toxic compounds. In addition, landfills may be economically unfeasible because of the large land area required (Chandra et al., 2008; Singh \& Agrawal, 2008). Thus, new methods for recycling and recovery of this organic waste are required (Ahlberg et al., 2006). Composting has long been recognized as one of the most costeffective and environmentally sound alternatives for organic waste recycling (Araújo \& Monteiro, 2006; Araújo et al., 2007; Singh et al., 2010). During composting, organic matter decomposes into carbon dioxide, water vapor, inorganic nutrients and stable organic material, containing humic substances (Senesi, 1989; Singh et al., 2010). Additionally, composting can reduce the concentration of pathogens and toxic organic compounds (Araújo \& Monteiro, 2005). This method has also been used to process sludge of different origins, including sewage and textile sludge (Bernal et al., 1998; Araújo \& Monteiro, 2006; Araújo et al., 2007; Singh et al., 2010).

The application of composted waste to agricultural soils requires caution due to the possibility of food chain contamination and negative effects on soil microorganisms, particularly rhizobia (Singh \& Agrawal, 2009, 2010). Little information is available about the toxic effects of composted industrial waste on soil microbiology and biochemical processes (Araújo \& Monteiro, 2007). Soil bacteria are important because of their role in biological $\mathrm{N}_{2}$ fixation, a process that has been identified as an important indicator of soil disturbances (Viser \& Parkinson, 1992). Brookes (1995) recommended the measurement of biological $\mathrm{N}_{2}$ fixation as an indicator of soil stress resulting from pollutants. Wetzel \& Werner (1995) reported that nodulation is an important property when examining the toxic effects of pollutants from compost application. There is currently a small number of studies on the effects of tannery sludge on soil microbial biomass and activity (Andre \& Mattiazzo, 1997; Konrad \& Castilhos, 2001); however, none of these focused specifically nodulation and biological $\mathrm{N}_{2}$ fixation in tropical legumes. Therefore, the purpose of this study was to evaluate the effect of tannery sludge compost (TSC) on growth, nodulation and $\mathrm{N}_{2}$ fixation of the cowpea plant. This study was an attempt to understand the response of the tested leguminous plant (cowpea) to the conflicting stimulation at on the one hand the beneficial effects of increased nutrient availability, on the other the harmful effects of heavy metal accumulation.

\section{MATERIAL AND METHODS}

Tannery sludge was collected from the wastewater treatment plant of the leather company "Curtume 
Europa" in Teresina, PI, Brazil. The sludge was composted for 85 days using the Beltsville aeratedpile method (USDA, 1980), stacked in two piles (sides $2 \times 1 \mathrm{~m}$, height $1.5 \mathrm{~m})$. The compost piles were turned over twice a week during the first and second week and once a week during the remaining bio-oxidative phase. The bio-oxidative phase of composting was considered finished when the temperature in the piles stabilized at around $30^{\circ} \mathrm{C}$, the temperature of the surrounding environment. This stage was reached after 55 days of composting. At this point, the compost was allowed to mature, without turning, for an additional 30 days. On the $85^{\text {th }}$ day, 20 subsamples were collected from several locations in each pile, to produce two composite samples. The chemical properties of both composite samples were determined by the EPA 3051 method (USEPA, 1986) (Table 1).

Two different soil types were collected with low and high-clay soils (sandy soil and clayey soil, respectively). Both soil types were sampled from the surface layer of the soil down to a depth of $10 \mathrm{~cm}$. The soil samples were air-dried, crushed and sieved $(2 \mathrm{~mm})$ to remove large fragments and the main physico and chemical properties of the soils assessed (Table 2). The soils were then amended with tannerysludge compost at rates of 0 (control), 7.5, 15, 30 and $60 \mathrm{t} \mathrm{ha}^{-1}$.

The compost was also air-dried and ground before mixing with the soils. Before filling the pots with the respective soil treatments, the separate heaps were mixed again to ensure that the compost was evenly distributed through the soil. The water-holding capacity of the final mixture was $40 \%$, using distilled water. A randomized complete block design with five treatments (tannery sludge rates of $0,7.5,15,30$, and $60 \mathrm{t} \mathrm{ha}^{-1}$ ) and four replicates per treatment was used for each soil type. For each treatment, soil types and replicates, $5 \mathrm{~kg}$ pots were filled to the respective level and left to stand for 10 days.

The cowpea seeds were inoculated with the commercial strain BR3262 of Bradyrhizobium elkanii (1 kg per $50 \mathrm{~kg}$ of seeds). Three seeds were sown per pot, at a depth of $0.5 \mathrm{~cm}$. After emergence, the seedlings were thinned to one plant per pot. The plants were harvested 30 and 45 days after emergence (DAE). The growth, nodule number and shoot dry weight and $\mathrm{N}$ accumulation (Keeney \& Nelson, 1982) were then measured. Shoots and roots were dried at $60{ }^{\circ} \mathrm{C}$ for $72 \mathrm{~h}$ before dry weight determination.

Table 2. Soil $\mathrm{pH}$, soil organic matter, total $\mathrm{P}$, total $\mathrm{N}$ and exchangeable $K$ contents in the sandy and clayey soils after amendment with tannery sludge compost

\begin{tabular}{|c|c|c|c|c|c|}
\hline Rate & pH & SOM & Total P & $\mathbf{K}$ & Total N \\
\hline $\mathrm{t} \mathrm{ha}^{-1}$ & & & 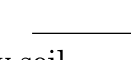 & $-\mathrm{mg} \mathrm{kg}^{-1}$ & \\
\hline \multicolumn{6}{|c|}{ Sandy soil } \\
\hline 0 & $6.4 \mathrm{~b}$ & $4.8 \mathrm{c}$ & $1.2 \mathrm{~b}$ & $7.1 \mathrm{c}$ & $0.11 \mathrm{~b}$ \\
\hline 7.5 & $7.6 \mathrm{a}$ & $5.7 \mathrm{~b}$ & $1.5 \mathrm{~b}$ & $7.9 \mathrm{c}$ & $0.34 \mathrm{~b}$ \\
\hline 15 & $7.7 \mathrm{a}$ & $5.8 \mathrm{~b}$ & $1.8 \mathrm{~b}$ & $7.7 \mathrm{c}$ & $0.41 \mathrm{~b}$ \\
\hline 30 & $7.7 \mathrm{a}$ & $6.1 \mathrm{a}$ & $2.3 \mathrm{a}$ & $10.8 \mathrm{~b}$ & $0.80 \mathrm{a}$ \\
\hline 60 & $7.8 \mathrm{a}$ & $6.3 \mathrm{a}$ & $2.5 \mathrm{a}$ & $14.1 \mathrm{a}$ & $0.95 \mathrm{a}$ \\
\hline \multicolumn{6}{|c|}{ Clayey soil } \\
\hline 0 & $6.5 \mathrm{c}$ & $4.6 \mathrm{c}$ & $1.1 \mathrm{~b}$ & $7.5 \mathrm{~b}$ & $0.09 \mathrm{c}$ \\
\hline 7.5 & $7.0 \mathrm{~b}$ & $5.5 \mathrm{~b}$ & $1.0 \mathrm{~b}$ & $7.6 \mathrm{~b}$ & $0.26 \mathrm{~b}$ \\
\hline 15 & $7.6 \mathrm{a}$ & $5.8 \mathrm{~b}$ & $1.3 \mathrm{a}$ & $7.6 \mathrm{~b}$ & $0.37 \mathrm{~b}$ \\
\hline 30 & $7.7 \mathrm{a}$ & $5.7 \mathrm{~b}$ & $1.4 \mathrm{a}$ & $13.2 \mathrm{a}$ & $0.75 \mathrm{a}$ \\
\hline 60 & $7.7 \mathrm{a}$ & $6.2 \mathrm{a}$ & $1.4 \mathrm{a}$ & $13.9 \mathrm{a}$ & $0.90 \mathrm{a}$ \\
\hline
\end{tabular}

In each column, means followed by the same letter do not differ statistically from each other at $p<0.05$ according to SNK's multiple range test.

Table 1. Chemical properties of composted dry tannery sludge (TSC)

\begin{tabular}{|c|c|c|}
\hline Property & TSC & Heavy metal limit \\
\hline $\mathrm{pH}$ & 7.8 & - \\
\hline Moisture content a $65^{\circ} \mathrm{C}(\%)$ & 42.7 & - \\
\hline Corg $\left(\mathrm{g} \mathrm{kg}^{-1}\right)$ & 187.58 & - \\
\hline Total N $\left(\mathrm{g} \mathrm{kg}^{-1}\right)$ & 1.28 & - \\
\hline Total $\mathrm{P}\left(\mathrm{g} \mathrm{kg}^{-1}\right)$ & 4.02 & - \\
\hline Exchangeable $\mathrm{K}\left(\mathrm{g} \mathrm{kg}^{-1}\right)$ & 3.25 & - \\
\hline Ex. Ca $\left(\mathrm{g} \mathrm{kg}^{-1}\right)$ & 95.33 & - \\
\hline Ex. $\mathrm{Mg}\left(\mathrm{g} \mathrm{kg}^{-1}\right)$ & 6.80 & - \\
\hline Total S $\left(\mathrm{g} \mathrm{kg}^{-1}\right)$ & 9.39 & - \\
\hline $\mathrm{Cu}\left(\mathrm{mg} \mathrm{kg}^{-1}\right)$ & 17.83 & 4,300 \\
\hline $\mathrm{Fe}\left(\mathrm{mg} \mathrm{kg}^{-1}\right)$ & $5,171.67$ & - \\
\hline $\mathrm{Mn}\left(\mathrm{mg} \mathrm{kg}^{-1}\right)$ & $1,848.73$ & - \\
\hline $\mathrm{Zn}\left(\mathrm{mg} \mathrm{kg}^{-1}\right)$ & 141.67 & 7,500 \\
\hline $\operatorname{Mo}\left(\mathrm{mg} \mathrm{kg}^{-1}\right)$ & 9.28 & - \\
\hline $\mathrm{Ni}\left(\mathrm{mg} \mathrm{kg}^{-1}\right)$ & 21.92 & 420 \\
\hline $\mathrm{Cd}\left(\mathrm{mg} \mathrm{kg}^{-1}\right)$ & 2.87 & 85 \\
\hline $\mathrm{Cr}\left(\mathrm{mg} \mathrm{kg}^{-1}\right)$ & $2,255.0$ & 3,000 \\
\hline $\mathrm{Pb}\left(\mathrm{mg} \mathrm{kg}^{-1}\right)$ & 42.67 & 75 \\
\hline
\end{tabular}

(1) CETESB (1999). 
Three soil samples per treatment were collected, air-dried, crushed, sieved $(2 \mathrm{~mm})$ and then stored separately for further chemical analyses. The $\mathrm{pH}$ of the soil samples and composted tannery sludge was measured in a 1:5 (w/v) suspension of soil to water. The organic $\mathrm{C}$ content of the soil was measured using the loss-on-ignition method at $550^{\circ} \mathrm{C}$. Total $\mathrm{N}$ was measured by the Kjeldahl and total $\mathrm{P}$ by the Olsen method. Exchangeable K, $\mathrm{Ca}$ and $\mathrm{Mg}$ were measured by extracting the soil sample with $1 \mathrm{~mol} \mathrm{~L}^{-1}$ $\mathrm{CH}_{3} \mathrm{COONH}_{4}$. Extractable $\mathrm{Zn}, \mathrm{Cu}, \mathrm{Fe}, \mathrm{Mo}, \mathrm{Mn}, \mathrm{Ni}$, $\mathrm{Cd}, \mathrm{Cr}$, and $\mathrm{Pb}$ were measured by extraction using DTPA, with quantitative determination by atomic absorption spectrometry (USEPA, 1986). Data were analyzed with analysis of variance (ANOVA) at $5 \%$ probability, using the Student-Newman-Keuls (SNK).

\section{RESULTS}

The tannery sludge compost (TSC) had a high $\mathrm{pH}$ (7.8) and high levels of organic C $\left(187.58 \mathrm{~g} \mathrm{~kg}^{-1}\right)$, total $\mathrm{N}\left(1.28 \mathrm{~g} \mathrm{~kg}^{-1}\right)$ and total $\mathrm{P}\left(4.02 \mathrm{~g} \mathrm{~kg}^{-1}\right)$, compared to both unamended soils (Tables 1 and 2). Additionally, high levels of all heavy metals studied were detected in the TSC, including $\mathrm{Ni}, \mathrm{Cd}, \mathrm{Cu}, \mathrm{Cr}$, and $\mathrm{Pb}$. The soil properties of the sandy and clayey soils were altered by TSC application (Tables 2 and 3).

The TSC also raised the heavy metal contents compared to unamended soil (Table 3). The $\mathrm{Cr}, \mathrm{Cu}$, $\mathrm{Cd}, \mathrm{Ni}$ and $\mathrm{Pb}$ content of the soils increased due to TSC application and increased with increasing amendment rates.

The shoot and root dry weight of cowpea plants in both soils was determined 30 and 45 DAE (Table 4).

Table 3. Heavy metals contents in the sandy and clayey soils after amendment with tannery sludge compost

\begin{tabular}{|c|c|c|c|c|c|}
\hline Rate & $\mathrm{Cr}$ & Cd & $\mathrm{Cu}$ & $\mathrm{Ni}$ & $\mathbf{P b}$ \\
\hline \multirow[t]{2}{*}{$\mathrm{tha}^{-1}$} & \multicolumn{5}{|c|}{$\mathrm{mg} \mathrm{kg}^{-1}$} \\
\hline & \multicolumn{5}{|c|}{ Sandy soil } \\
\hline 0 & $2.1 \mathrm{e}$ & $0.052 \mathrm{c}$ & $1.46 \mathrm{~b}$ & $0.782 \mathrm{c}$ & $17.5 \mathrm{~b}$ \\
\hline 7.5 & $32.4 \mathrm{~d}$ & $0.068 \mathrm{c}$ & $1.62 \mathrm{~b}$ & $0.912 \mathrm{~b}$ & $15.7 \mathrm{~b}$ \\
\hline 15 & $89.8 \mathrm{c}$ & $0.130 \mathrm{~b}$ & $1.53 \mathrm{~b}$ & $1.028 \mathrm{~b}$ & $20.4 \mathrm{a}$ \\
\hline 30 & $117.8 \mathrm{~b}$ & $0.138 \mathrm{~b}$ & $1.68 \mathrm{~b}$ & $1.150 \mathrm{a}$ & $18.3 \mathrm{a}$ \\
\hline 60 & $162.0 \mathrm{a}$ & $0.162 \mathrm{a}$ & $2.31 \mathrm{a}$ & $1.188 \mathrm{a}$ & $18.8 \mathrm{a}$ \\
\hline \multicolumn{6}{|c|}{ Clayey soil } \\
\hline 0 & $2.3 \mathrm{e}$ & $0.062 \mathrm{~d}$ & $1.44 \mathrm{~b}$ & $0.612 \mathrm{a}$ & $16.5 \mathrm{a}$ \\
\hline 7.5 & $24.1 \mathrm{~d}$ & $0.074 \mathrm{c}$ & $1.43 \mathrm{~b}$ & $0.754 \mathrm{a}$ & $15.2 \mathrm{a}$ \\
\hline 15 & $54.2 \mathrm{c}$ & $0.094 \mathrm{~b}$ & $1.22 \mathrm{~b}$ & $0.586 \mathrm{a}$ & $13.6 \mathrm{a}$ \\
\hline 30 & $85.4 \mathrm{~b}$ & $0.096 \mathrm{~b}$ & $1.20 \mathrm{~b}$ & $0.368 \mathrm{a}$ & $11.7 \mathrm{a}$ \\
\hline 60 & $148.4 \mathrm{a}$ & $0.102 \mathrm{a}$ & $1.79 \mathrm{a}$ & $0.476 \mathrm{a}$ & $15.6 \mathrm{a}$ \\
\hline
\end{tabular}

In the columns, means followed by the same letter do not differ statistically from each other at $\mathrm{p}<0.05$, according to the SNK test.
The shoot dry weight of cowpea did not vary significantly between soil types 30 DAE. However, 45 DAE in clayey soil, dry weight was higher than in unamended soil. In sandy soil, 45 DAE, cowpea shoot dry weight increased at TSC rates of $30 \mathrm{tha}^{-1}$, but decreased at $60 \mathrm{t} \mathrm{ha}^{-1}$. The cowpea root dry weight did not vary significantly between soil types 30 or 45 DAE (Table 4).

The number of cowpea root nodules did not vary significantly in either evaluation (Table 5). However, the nodule dry weight in the sandy soil did respond to TSC. Nodule dry weight was greater than in unamended soil $45 \mathrm{DAE}$, but did not vary significantly between treatment levels. In the clayey soil, $30 \mathrm{DAE}$, nodule dry weight did not vary significantly with increasing TSC amendment rate. However, nodule dry weight decreased $45 \mathrm{DAE}$ for TSC amendment rates greater than $7.5 \mathrm{t} \mathrm{ha}^{-1}$ compared to the unamended soil (Table 5).

Nitrogen accumulation increased for the cowpea in both soil types with increasing TSC amendment rates in both evaluations, compared with unamended soil (Table 6). However, the variation between the treatments was insignificant, with the exception of the $60 \mathrm{t} \mathrm{ha}^{-1}$ treatment $45 \mathrm{DAE}$ in/ clayey soil.

\section{DISCUSSION}

The application of TSC affected the soil physical and chemical properties in this experiment. Because of the high $\mathrm{pH}$ of the compost, its addition to the soil raised the soil $\mathrm{pH}$ according to the different TSC amendment rates. The high levels of organic matter,

Table 4. Changes in shoot and root dry weight of cowpea grown in soils amended with composted tannery sludge

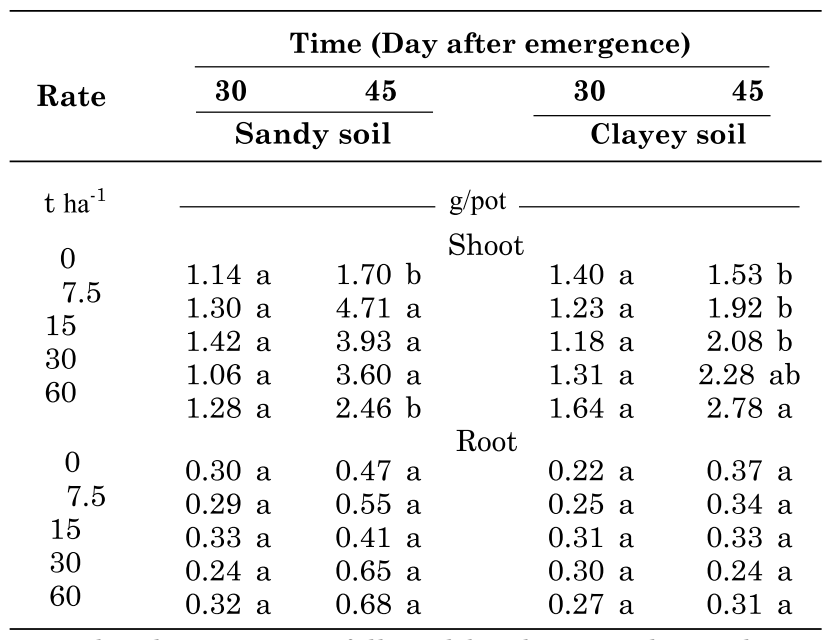

In each column, means followed by the same letter do not differ statistically from each other at $\mathrm{p}<0.05$, according to the SNK test. 
Table 5. Changes in nodule number (nodules per pot) and nodule dry weight (mg per pot) of cowpea growing in soils amended with composted tannery sludge

\begin{tabular}{|c|c|c|c|c|}
\hline \multirow{3}{*}{ Rate } & \multicolumn{4}{|c|}{ Time (Day after emergence) } \\
\hline & 30 & 45 & 30 & 45 \\
\hline & \multicolumn{2}{|c|}{ Sandy soil } & \multicolumn{2}{|c|}{ Clayey soil } \\
\hline $\mathrm{t} \mathrm{ha}^{-1}$ & \multicolumn{4}{|c|}{$\begin{array}{l}\text { Nodule number } \\
\text { (nodules per pot) }\end{array}$} \\
\hline 0 & $14 \mathrm{a}$ & $53 \mathrm{a}$ & $15 \mathrm{a}$ & $68 \mathrm{a}$ \\
\hline 7.5 & $24 \mathrm{a}$ & $25 \mathrm{a}$ & $25 \mathrm{a}$ & $62 \mathrm{a}$ \\
\hline 15 & $17 \mathrm{a}$ & $33 \mathrm{a}$ & $10 \mathrm{a}$ & $37 \mathrm{a}$ \\
\hline 30 & $28 \mathrm{a}$ & $40 \mathrm{a}$ & $18 \mathrm{a}$ & $54 \mathrm{a}$ \\
\hline 60 & $14 \mathrm{a}$ & $40 \mathrm{a}$ & $12 \mathrm{a}$ & $52 \mathrm{a}$ \\
\hline \multicolumn{5}{|c|}{$\begin{array}{l}\text { Nodule dry weight } \\
\text { (mg per pot) }\end{array}$} \\
\hline 0 & $26.9 \mathrm{a}$ & $42.1 \mathrm{a}$ & $30.3 \mathrm{~b}$ & $65.2 \mathrm{a}$ \\
\hline 7.5 & $30.4 \mathrm{a}$ & $137.2 \mathrm{a}$ & $39.1 \mathrm{a}$ & $69.5 \mathrm{a}$ \\
\hline 15 & $30.1 \mathrm{a}$ & $119.4 \mathrm{a}$ & $5.1 \mathrm{c}$ & $12.9 \mathrm{~b}$ \\
\hline 30 & $27.3 \mathrm{a}$ & $139.6 \mathrm{a}$ & $3.4 \mathrm{c}$ & $3.4 \mathrm{c}$ \\
\hline 60 & $19.9 \mathrm{a}$ & $141.5 \mathrm{a}$ & $6.0 \mathrm{c}$ & $11.3 \mathrm{~b}$ \\
\hline
\end{tabular}

In each column, means followed by the same letter do not differ statistically from each other at $p<0.05$ according to the SNK test.

Table 6. Changes in $\mathrm{N}$ accumulation (mg/pot $\mathrm{N})$ of cowpea growing in soils amended with composted tannery sludge

\begin{tabular}{|c|c|c|c|c|}
\hline \multirow{3}{*}{ Rate } & \multicolumn{4}{|c|}{ Time (Day after emergence) } \\
\hline & 30 & 45 & 30 & 45 \\
\hline & \multicolumn{2}{|c|}{ Sandy soil } & \multicolumn{2}{|c|}{ Clayey soil } \\
\hline$t h a^{-1}$ & \multicolumn{4}{|c|}{$\begin{array}{l}\mathrm{N} \text { content } \\
\text { (mg per pot) }\end{array}$} \\
\hline 0 & $26.5 \mathrm{~b}$ & $32.0 \mathrm{a}$ & $73.0 \mathrm{~b}$ & $66.0 \mathrm{c}$ \\
\hline 7.5 & $31.5 \mathrm{a}$ & $28.2 \mathrm{~b}$ & $84.0 \mathrm{a}$ & $72.8 \mathrm{~b}$ \\
\hline 15 & $31.6 \mathrm{a}$ & $28.3 \mathrm{~b}$ & $92.6 \mathrm{a}$ & $76.0 \mathrm{~b}$ \\
\hline 30 & $31.9 \mathrm{a}$ & $29.2 \mathrm{~b}$ & $94.5 \mathrm{a}$ & $76.8 \mathrm{~b}$ \\
\hline 60 & $31.2 \mathrm{a}$ & $29.7 \mathrm{~b}$ & $95.8 \mathrm{a}$ & $83.9 \mathrm{a}$ \\
\hline
\end{tabular}

In each column, means followed by the same letter do not differ statistically from each other at $p<0.05$ according to the SNK test.

nutrients and heavy metals in TCS increased the concentrations of these components at the different compost rates.

One of the most important benefits of sludge application to agricultural soil is the increased availability of beneficial nutrients (Singh \& Agrawal, 2007, 2009, 2010). Gupta \& Sinha (2007) reported an increase in different chemical properties, such as organic matter and available nutrient and heavy metal contents, at different tannery sludge soil amendment rates. Other authors reported an increase in soil chemical properties due to sewage sludge amendment (Logan \& Harrison, 1995; Moreno et al., 1997; Singh \& Agrawal, 2007, 2009, 2010). The exchangeable concentration of phytoavailable heavy metals, such as DTPA, increased significantly with each TSC amendment rate. Phytoavailability of heavy metals is determined by several factors, such as the nature of the metal species, its interaction with soil colloids, soil properties and the duration of contact with the surface of the metals (Naidu et al., 2003). Concentrations of phytoavailable heavy metals in both soils increased along with higher amendment rates. Ailincai et al. (2007) found a similar trend for $\mathrm{Cu}, \mathrm{Ni}$ and $\mathrm{Cr}$ at sewage sludge amendment rates of 40 and $60 \mathrm{t} \mathrm{ha}^{-1}$. The heavy metal concentration of the tannery sludge used in this study was found to be lower than in sludge produced by a tannery studied by Gupta \& Sinha (2007) in India. In addition, after amendment the heavy metal concentrations were below the thresholds established by the Brazilian legislation (CETESB, 1999). The Cr content of the sludge did however not meet the more restrictive standards set by Brazilian law for use in agricultural soil. The values of $\mathrm{Cr}, \mathrm{Cd}, \mathrm{Ni}$ and $\mathrm{Pb}$ were found to be far below the range proposed by Lake (1987) for agricultural soils. Especially for $\mathrm{Cr}$, the content observed after the TSC application of $7.5 \mathrm{t} \mathrm{ha}^{-1}$ was below the limit of $50 \mathrm{mg} \mathrm{kg}^{-1}$ proposed by Barceló \& Poschenrieder (1992). On the other hand, the $\mathrm{pH}$ values of the soils in this study ranged from 6.4 to 7.8 (Table 2), indicating that almost all $\mathrm{Cr}$ was insoluble (Bartlett \& James, 1988).

The plant response to environmental stress is determined by the response of its individual cells. Cell integrity as well as structure are affected (Ciamporova \& Mistrik, 1993; Ouzounidou et al., 1995). The plant response to heavy metal stress may also depend on how the metal ions are distributed between the plant tissues and within the cells that constitute these tissues (Ouzounidou et al., 1995). The decrease in shoot dry weight $45 \mathrm{DAE}$ in the sandy soil for the samples with highest TSC rate indicated a toxic effect of heavy metals on cowpea in sandy soil. These results are in agreement with the findings of Eivazi (1990) and of Araújo \& Monteiro (2006), who observed a decrease in dry weight after applying high rates of sewage sludge or textile sludge compost. Singh \& Agrawal (2007) also reported significant reductions in the root and shoot dry weight of palak plants growing at 20 and $40 \%$ sewage sludge amendment rates, compared to the unamended control. Alvarez et al. (1995) reported that plant growth significantly increased compared to control plants when manure compost was added to soil. Wong et al. (1999) reported that the addition of manure compost increased total organic matter, macronutrients and micronutrients according to the compost application rate. Increased plant growth has been attributed to increased levels of organic matter and nutrients in amended soils.

There have been conflicting reports on the effects of sludge on nodulation and $\mathrm{N}$ fixation of legumes (Angle et al., 1992). Some papers reported that heavy metals inhibited nodulation significantly (Abd-Alla et 
al., 1999). Singh \& Agrawal (2010) reported that the number of nodules was significantly higher in Vigna radiata at sewage sludge rates of 6 and $9 \mathrm{~kg} \mathrm{~m}^{-2}$ than in unamended control plants. At higher levels however, nodulation decreased. In this study, it was shown that nodule numbers were not negatively affected by the heavy metals present in TSC. Nodule mass, however, was negatively affected by the application of TSC at high rates in the clayey soil. In the clayey soil, heavy metals are bounded to clay particles which decreased the availability of some important metals that promote increase in nodule mass. The higher accumulation of $\mathrm{N}$ in plant shoots grown in amended soil, compared to the control, is most likely a result of the high $\mathrm{N}$ levels of the composted tannery sludge.

In the light of this study appear several opportunities for further study. It is important to verify whether the inoculation of cowpea with strain 3262 resulted in increases plant growth. It is fundamental to further study the effects of tannery compost on yields. It is therefore essential to evaluate the heavy metal contents transferred to the plants, to avoid any negative impact (Hue, 1995). Additionally, applications at lower rates would be important for both economic and environmental reasons.

In legume production, some environmental and economic advantages are associated with $\mathrm{N}_{2}$-fixing microorganisms. Due to these microorganisms, inoculated legumes have an increased capacity to survive, compared to non-inoculated plants, because they have an additional nutritional alternative. Sewage sludge applied to an inoculated legume crop increase the availability of plant nutrients; however, the toxic heavy metals present in the sludge can inhibit biological $\mathrm{N}$ fixation (Broos et al., 2005).

\section{CONCLUSIONS}

1. Application of tannery sludge compost increased shoot $\mathrm{N}$ accumulation and organic $\mathrm{C}, \mathrm{N}, \mathrm{P}$ and heavy metal contents.

2. The shoot biomass was highest at TCS rates of 30 and $60 \mathrm{tha}^{-1}$ in sandy and clayey soil, respectively.

3. Nodule weight was affected positively by TSC amendment of the sandy soil, but was negatively affected in the clayey soil at TSC rates higher than $7.5 \mathrm{t} \mathrm{ha}^{-1}$.

\section{ACKNOWLEDGEMENTS}

The authors are indebted to the company Curtume Europa for providing the tannery sludge for composting. This research was funded by "Conselho Nacional de Desenvolvimento Científico e Tecnológico"
(CNPq-Brazil). The authors A.S.F Araújo, W.J. Melo and M.V.B. Figueiredo were supported by personal grants from CNPq-Brazil.

\section{LITERATURE CITED}

ABD-ALLA, H.M.; YAN, F. \& SCHUBERT, S. Effects of sewage sludge application on nodulation, nitrogen fixation and plant growth of faba bean, soybean and lupin. J. Appl. Bot., 73:69-75, 1999.

AHLBERG, O.; GUSTAFSSON, P. \& WEDEL, F. Leaching of metals from sewage sludge during one year and their relation to particle size. Environ. Poll., 144:545-553, 2006.

AILINCAI, C.; JITAREANU, G.; BUCUR, D. \& AILINCAI, D. Influence of sewage sludge on maize yield and quality and soil chemical characteristics. J. Food Agric. Environ., 5:310-313, 2007.

ANDRÉ, E.M. \& MATTIAZZO, M.E. Biodegradabilidade de um resíduo de curtume aplicado a latossolos. In: CONGRESSO BRASILEIRO DE CIENCIA DO SOLO, 26., 1997, Rio de Janeiro. Resumos Expandidos... Rio de Janeiro: SBCS, 1997. CD-ROM.

ALVAREZ, R.; DOAZ, R.A.; BARBERI, N.; SANTANATOGLIA, O.J. \& BALOTA, L. Soil organic carbon, microbial biomass and $\mathrm{CO}_{2}-\mathrm{C}$ production from tree tillage systems. Soil \& Tillage Research, 33:17-28, 1995.

ANGLE, J.S.; MADARIAGA, G.M. \& HEGER, E.A. Sewage sludge effects on growth and nitrogen fixation of soybean. Agric. Ecosyst. Environ., 41:231-239, 1992.

ARAÚJO, A.S.F. \& MONTEIRO, R.T.R. Plant bioassays to assess toxicity of textile sludge compost. Sci. Agric., 62:286$290,2005$.

ARAÚJO, A.S.F. \& MONTEIRO, R.T.R. Microbial biomass and activity in a Brazilian soil plus untreated and composted textile sludge. Chemosphere, 64:1043-1046, 2006.

ARAÚJO, A.S.F.; MONTEIRO, R.T.R. \& CARVALHO, E.M.S. Effect of composted textile sludge on growth, nodulation and nitrogen fixation of soybean and cowpea. Biores. Technol., 97:1028-1032, 2007.

BARCELÓ, J. \& POSCHENRIEDER, C. Respuestas de las plantas a la contaminación por metales pesados. Suelo Planta, 2:345-361, 1992.

BARTLETT, R.J. \& JAMES, B.R. Mobility and bioavailability of chromium in soils. In: NRIAGU, J.O. \& NIEBOER, E., ed. Chromium in the natural and human environments. New York, J. Wiley \& Sons, 1988. p.267-304.

BERNAL, M.P.; PAREDES, C.; SANCHEZ-MONEDERO, M.A. \& CEGARRA, J. Maturity and stability parameters of compost prepared with a wide range of organic wastes. Biores. Technol., 63:91-99, 1998.

BROOKES, P.C. The use of microbial parameters in monitoring soil pollution by heavy metals. Biol. Fert. Soils, 19:261-279, 1995. 
BROOS, K.; BEYENS, H. \& SMOLDERS, E. Survival of rhizobia in soil is sensitive to elevated zinc in the absence of the host plant. Soil Biol. Biochem., 37:573-579, 2005.

CASTILHOS, D.D.; TEDESCO, M.J. \& VIDOR, C. Rendimentos de culturas e alterações químicas do solo tratado com resíduos de curtume e crômio hexavalente. R. Bras. Ci. Solo, 26:1083-1092, 2002.

CETESB. Aplicação de Biossolidos em áreas agrícolas: Critérios para projeto e operação. Norma P4230. São Paulo, 1999. $32 \mathrm{p}$.

CHANDRA, R.; YADAV, S. \& MOHANB, D. Effect of distillery sludge on seed germination and growth parameters of green gram (Phaseolus mungo L.) J. Haz. Mat., 152:431439, 2008

CIAMPOROVA, M. \& MISTRIK, J. The ultra structural response of root cells to stressful conditions. Environ. Exper. Bot., 33:11-26, 1993.

EIVAZI, F. Nitrogen fixation of soybean and alfafa on sewage sludge-amended soils. Agric Ecosyst. Environ., 30:129. $136,1990$.

GUPTA, A.K. \& SINHA, S. Phytoextraction capacity of the plants growing on tannery sludge dumping sites. Biores. Technol., 98:1788-1794, 2007.

HUE, N.V. Sewage sludge. In: RECHCIGL, J.E., ed. Soil amendments and environmental quality. Boca Raton, CRC Press, 1995. p.168-199.

KEENEY, D.R. \& NELSON, D.W. Nitrogen-inorganic forms. In: PAGE, A.L.; MILLER, R.H. \& KEENEY, D.R., eds. Methods of soil analysis. Chemical and microbiological propreties. Madison, American Society of Agronomy, Soil Science Society of America, 1982. Part 2. p.643-698.

KONRAD, E.E. \& CASTILHOS, D.D. Atividade microbiana em um planossolo após a adição de resíduos de curtume. $\mathrm{R}$ Bras. Agrociência, 7:131-135, 2001.

LAKE, D.L. Sludge disposal to land. In: LESTER, J.N., ed. Heavy metals in wastewater and sludge treatment process. Boca Raton, CRC Press, 1987. p.91-130.

LOGAN, T.J. \& HARRISON, B.J. Physical characteristics of alkaline stabilized sewage sludge (N-Viro Soil) and their effects on soil physical properties. J. Environ. Quality, 24:153-164, 1995.

MORENO, J.L.; GARCIA, C.; HERNANDEZ, T. \& AYUSO, M. Application of composted sewage sludges contaminated with heavy metals to an agricultural soil: Effect on lettuce growth. Soil Sci. Plant Nutr., 4:565-573, 1997.

NAIDU, R.; BOLAN, N.S. \& ADRIANO, D.C. eds. Bioavailability, toxicity and risk relationships in ecosystems: the path ahead. In: Bioavailability and its Potential Role in Risk Assessment. Science Publishers, New York, 2003. p.331339.
OUZOUNIDOU, G.; CIAMPOROVÁ, M.; MOUSTAKAS, M. \& KARATAGLIS, S. Responses of maize (Zea mays L.) plants to copper stress-I. Growth, mineral content and ultrastructure of roots. Environ Exper. Bot., 35:167-176, 1995.

PACHECO, J.W.F. Curtumes. São Paulo, CETESB, 2009.

SENESI, N. Composted materials as organic fertilizers. Sci. Total Environ., 81/82:521-542, 1989.

SILVEIRA, I.C.T.; ROSA, D.; MONTEGGIA, L.O.; ROMEIRO, G.A.; BAYER, E. \& KUTUBUDDIN, M. Low temperature conversion of sludge and shavings from leather industry. Water Sci. Technol., 46:277-283, 2002.

SINGH, R.P. \& AGRAWAL, M. Effects of sewage sludge amendment on heavy metal accumulation and consequent responses of Beta vulgaris plants. Chemosphere, 67:22292240, 2007.

SINGH, R.P. \& AGRAWAL, M. Effect of different sewage sludge application on growth and yield of Vigna radiata L. field crop: Metal uptake by plant. Ecol Eng., 36:969972, 2010

SINGH, R.P. \& AGRAWAL, M. Potential benefits and risks of land application of sewage sludge. Waste Manag., 28:347. 358,2008

SINGH, R.P. \& AGRAWAL, M. Use of sewage sludge as fertilizer supplement for Abelmoschus esculentus plants: Physiological, biochemical and growth responses. Inter. J. Environ. Waste Manag., 3:91-106, 2010.

UNITED STATES DEPARTMENT OF AGRICULTURE USDA. Manual for composting of sewage sludge by the Beltsville aerated-pile method. Washington, 1980. p.65.

UNITED STATES ENVIRONMENTAL PROTECTION AGENCY - USEPA. Test method for evaluating solid wastes. Washington, 1986. p.255. (Report Number, SW846)

VISER, S. \& PARKINSON, D. Soil biological criteria as indicator of soil quality: Soil microorganisms. Am. J. Altern. Agric., 7:33-37, 1992

WETZEL, A. \& WERNER, D. Ecotoxicological evaluation of contaminated soil using the legume root nodule symbiosis as effect parameters. Environ. Toxicol. Water Qual., 10:127-133, 1995

WONG, J.W.C.; LAI, K.M.; FANG, M. \& MA, K.K. Effect of sewage sludge amendment on soil microbial activity and nutrient mineralization. Environment International, 24:935-943, 1998. 
